HABITAT, 28 (3), 2017, 114-121

DOI: 10.21776/ub.habitat.2017.028.3.16

\title{
Changes in Socio-Economic and Cultural Behavior of Female Indonesian Migrant Workers
}

\author{
Keppi Sukesi ${ }^{1 *}$, Endang Setyowati ${ }^{2}$, Agustina Shinta Hartati Wahyuningtyas ${ }^{3}$, Nur Baladina ${ }^{4}$ \\ ${ }^{1 *}, 3,4$ Socio-Economics Department, Faculty of Agriculture, Brawijaya University, Jl. Veteran, \\ 65145, Indonesia \\ ${ }^{2}$ Faculty of Husbandry, Brawijaya University, Jl. Veteran, 65145, Indonesia
}

Received: 30 September 2017; Revised: 2 November 2017; Accepted: 1 December 2017

\begin{abstract}
Indonesian Migrant Workers (BMI) is a development hero that contributes to reducing the national poverty rate; however, the departure of BMI abroad has an impact on the change of BMI and their families. This study aims to analyze the changes that occur in the socio-economic and cultural sectors. The results showed that there was a change of socio-economic and cultural behavior of full-time BMI women in the village of Majangtengah after they returned to the area of origin. Social change occurs in the family to the community. At the family level there is a change in the structure and function of the family because of the absence of a mother in the household. The core family structure is transformed into a widespread family, with no mother, the BMI who joins the family of origin. The second structure is to survive with the core family minus the mother, or father to be single parent. The third form is the children living alone at home because there is no parent or relative guarding.
\end{abstract}

Keywords: BMI; socio-economic changes; cultural changes

\section{How to cite:}

Sukesi, K., Setyowati, E., Wahyuningtyas, A. S. H., \& Baladina, N. (2017). Changes in SocioEconomic and Cultural Behavior of Female Indonesian Migrant Workers. HABITAT, 28(3), 114-121. https://doi.org/10.21776/ub.habitat.2017.028.3.16

\section{Introduction}

Workforce is the actors of development and economic activity both individually and in-groups who have a very significant role in the national economic activity. Based on the 2010 population census issued by the Indonesian Central Bureau of Statistics, the total population of Indonesia is $237,641,326$ people. With a population of nearly a quarter of a billion, Indonesia faced such employment problem so that it encourages Indonesian people to migrate abroad as Indonesian Migrant Workers or IMW (Buruh Migran Indonesia or BMI) both in formal sector as professionals and non-formal sectors.

Wijaya (2012) found that the majority of IMWs who work in non-formal areas as in households are from poor regions and families, have low education level and social status, and lack of professional work skills. It is clear that their conditions in the foreign country are so vulnerable so that a protection is highly required. A protection should be provided from recruitment, placement, in the workplace, until they return to the hometown (Wijaya,
1999). On the other hand, Sukesi (2005) examined the impact of international migration on IMWs family structure which indicates that there has been a change in the structure. With the absence of a mother in the family (married IMWs), the function of family and childcare is taken over by the husband or other family members.

After the migration, female IMWs show that when they return to Indonesia, they are not ready to work independently in the home areas. Their earnings are used for consumptive purposes and not for productive purposes nor business capital such as for farming, trading, crafting, and so on which might be able to reduce or eliminate the dependence of women to work abroad (Wijaya, 2012). Not all female IMWs are able to utilize their earnings while working abroad as entrepreneurship capital. This also happens to the families, not all of them capable to manage remittances as entrepreneurship capital. This has led to the dependence of IMWs to work abroad again when their savings have run out. 
Remittances are one of the results of IMWs sent to their families. According to Rapoport and Docquier (2005), remittances are used to pay loans for migration, education, financial strategies, and insurance. Remittances can have social impacts such as changes in behavior, lifestyle, and labor in the origin (Primawati, 2011). The positive strength of remittances will arise because remittances can make changes in rural areas such as increasing the income of each individual, creating investment, and increasing social mobility (Curson, 1981).

The research conducted by Cuong (2009) showed that remittance and welfare have a positive correlation because remittances can improve the welfare of migrant workers in the hometown. Remittances can increase family income as reflected in the increased family welfare through increased household consumption, education, and health service. Remittances have a direct impact on disposable income for the recipients which are allocated for consumption or savings activities (Barbone et al., 2012). Remittances also have a big contribution in improving the standard of living of migrant families in the hometown. Remittances were initially devoted solely to consumption activities by migrant families but now have gradually shifted to investment (Connell and Brown, 1995).

Irawaty and Wahyuni (2012) mentioned that the amount of remittances from migrant workers to the families is influenced by several factors such as migrant age, marriage status, wages, type of mobility, duration of migration, and education. Remittances can be utilized optimally if they are close to the pattern proposed by Friedmann (1992) namely basic consumption, long-term investment, and investment in capacity building and family competence.

Based on previous research, IMWs, especially women, choose to work abroad. However, there is an impact of change that happened while remittances are one of the results from IMWs during work abroad. Therefore, the purpose of this study is to analyze the behavioral changes in the culture and socio-economics of retired IMWs (female).

\section{Research Method}

This study used a descriptive method. The descriptive method itself has 4 methods, one of which is a case study. A case study is a method that aims to study real symptoms in a society (Wiyarti and Mulya, 2007). This case study research was carried out in one of the villages in Malang which is the center to send female IMWs.

\section{Research Results}

The results show that there was a change in the socio-economic and cultural behavior of full-time female IMWs in Majangtengah village after they returned to their hometown. The social change occurs in the family and community environment. At the family level, there is a change in the family structure and function because of the absence of a mother in the household. The core family structure is transformed into a wide structure of a family with no mother, which is the IMWs who join the family. The second structure is to survive a family with no mother or the father to be a single parent. Meanwhile, the third structure is the children have to live alone because there is no parents or relatives.

The ability of domestic actors to adapt to the new field as a reality often goes against their habits and habitus. The closeness of the environment such as the family and society will influence the family structure that is left behind by the female IMWs. This is what Bordeau calls as social practice; the changes in the family structure followed by the changes in family function. This is the role of the surrogate mother in IMWs household that entrusted her family to other household members. A husband who is, conventionally, the main breadwinner has a double role as husband and wife to earn a living for the family. As a single parent, the husband also has double work which is in-house and outside the household. There also a phenomenon that children take over the responsibilities of the parents. The eldest child would take care of his/her younger siblings.

In this case, work culture also experiences a change. The division of livelihoods, the domestic-public sector, applies normatively. In Majangtengah village, the people consider that women's work is an additional job while men are the main workers although, in fact, men and women work together. When working abroad, female IMWs feel that they have a real job for the families. Their main motivation is to build houses and 
buy furniture. It is known that some are successful and some are unsuccessful.

The habitus or home environment of IMWs family in Majangtengah village has established motivation, attitude, and spirit of work. Work environment as the domain of IMWs struggle determines the success of the workers. Adaptability is a very important internal capital of IMWs which shapes the behavior or practice of female IMWs. Culture, limited IMWs capital, employers, and working atmosphere are believed to shape the attitudes and behaviors of female IMWs. Cultural adaptation in the workplace helps the IMWs to adapt the environment that sometimes is strange for the IMWs. Economic changes can be seen in Giatin family who use remittances as additional capital for the birdcage business. The additional capital from working as IMWs in Saudi Arabia is able to increase the income from IDR 3,000,000 per month to IDR $4,500,000$ per month. Winarsi who also worked in Saudi Arabia for 8 years can buy 2 hectares of rice field. One hectare is planted with sugarcane while the other one hectare is planted with papaya, chili, and sengon tree. The family who used to work as agricultural laborers now have income from their own fields.

The most prominent economic change can be seen in Luluk family who worked in Saudi Arabia for 30 years with her husband. She was able to buy 1,5 hectares of dry land and 0,5 hectares of rice field. In addition, she was able to open a productive business which is farm shop and garage. She also built a house for rent in Malang. The children are taken care by their grandmother from childhood until married. In their adulthood, they manage the productive efforts of their parents.

"Who manages all the land is the first son and niece. Earnings from the sugarcane and paddy yields are a profit-sharing system. $70 \%$ of the yield from rice field and sengon tree are given to Luluk and the remaining 30\% are given to the nephew. The income from the rice field during the planting cycle is IDR $12,000,000 /$ season but it becomes IDR $8,400,000 /$ season because of the profitsharing system. The income from the sengon tree is as much as IDR 40,000,000/season and becomes IDR 28,000,000 due to the profitsharing system. Up to now, the sengon tree has been harvested 4 times."

Today, the families who used to work as farm laborers could earn an average of IDR $4,000,000$ every month. The ability to manage remittances and a conducive workplace in Saudi Arabia is the key to the success of this family. Not all female IMWs could success from their work. Jumiati, Mistina, and Ponimah are the example of failed IMWs. The failure of IMWs is caused by the inability to manage remittances into productive business, lack of trading skills, and big consumptive soul of the family. The limited environment of Majangtengah village, the low employment, and wages, small capital, as well as no social capital support from the family and the village, resulted in the failure of Ponirah, Mistina, and Jumiati to utilize their earnings as a source of income.

Investment is a term which has several related senses with finance and economy. This is related to one's investment that is expected to get profit in the future. The meaning of capital in this research is the number of remittances owned by the migrant workers especially the ex-workers (female) who originated from the results of the salary as they work in foreign country.

The investment decision is the way someone allocates their money into an investment. Indonesian Labor generally has much money after they work in a foreign country compared with people who work in their own country. Almost all of them allocate their remittances into some form of investment. It is proved from one of the survey results. The survey compared the house of female IMWs with the house of women who work in the home country. Mostly, female IMWs choose to invest the money for the development of their house and so on. They also choose to utilize the money as a business capital as an effort to maintain their financial status after becoming IMWs in the form of building construction, saving, education, vehicles, and others. 


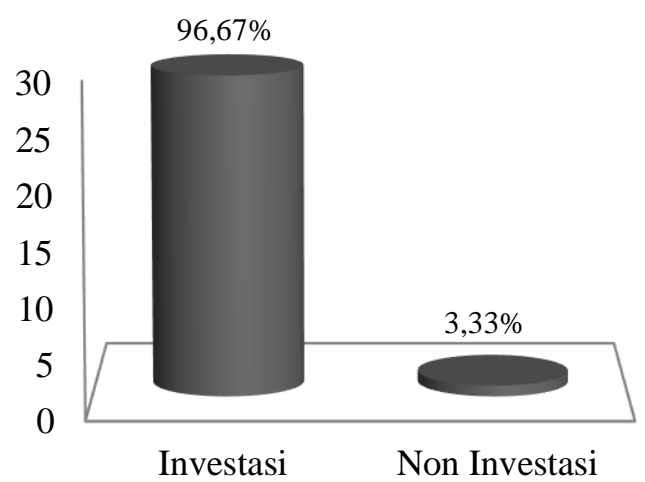

Figure 1. Investment Decision

Based on the results of a survey (interview) with 30 informants described in Figure 1 above, almost all of them invest the money. There are 29 informants with a percentage of $96,67 \%$ who choose to invest their remittances in various forms of investment. Their decision to invest the money is to improve the family condition in terms of asset ownership and to help the family economic condition. They expect that the remittances obtained can be useful and beneficial in the future.

According to the data from the picture above, there is 1 informant with a percentage of $3,33 \%$ that does not invest her remittances into any form. This is due to several factors, one of which is family harmony. The informant did not use her money well because she had problems with remittance delivery patterns. The remittance money sent home was not delivered to her husband but through her siblings. The corresponding informant did not give a definite reason why she sent money through her siblings and not her husband.

The impact of remittances while working abroad does not appear to be visible because the remittances were spent by her siblings. When the siblings were asked about the money, their answers were always the same. They said that the money was already run out, the ATM was broken, and the account book was on fire. After hearing the reason many times, she never talked about it again because if they will always give the same answer. Until now, they are not in a good relationship. The explanation above is reinforced by the informant's statement as follows: "...well, I do not want to know... I do not want to remember that. I work desperately but I do not get anything from Saudi. This gold right here is from my husband... everything... the furniture also. I get nothing from work. All of which were washed out by my siblings. They are not close to me anymore. They said that the money already out, the ATM is not active anymore, and the account book was on fire... So... I do not want to discuss it again, there is nothing I can do..." Mrs. Jumiati, 48 years old.

The female workers utilize the remittances money from a foreign country as a capital for investment to fix their economic condition. Each informant in the research not only invest in one type of investment but in several types of investment. This following Figure 2 explains the investment types made from remittances of the female workers.

Based on Figure 2, the types of investment made by the female workers in Majangtengah village are very diverse. In this research, the investment is grouped into 10 categories namely small livestock, big livestock, agroindustry, business, education, buying or renting agriculture land, renovation/house making, vehicles (cars \& motorcycles), as well as savings and gold. The types of investment proposed by Retno (2014) are the investment in the form of capital goods, development, education, and savings including the common types of investment generally performed by IMWs.

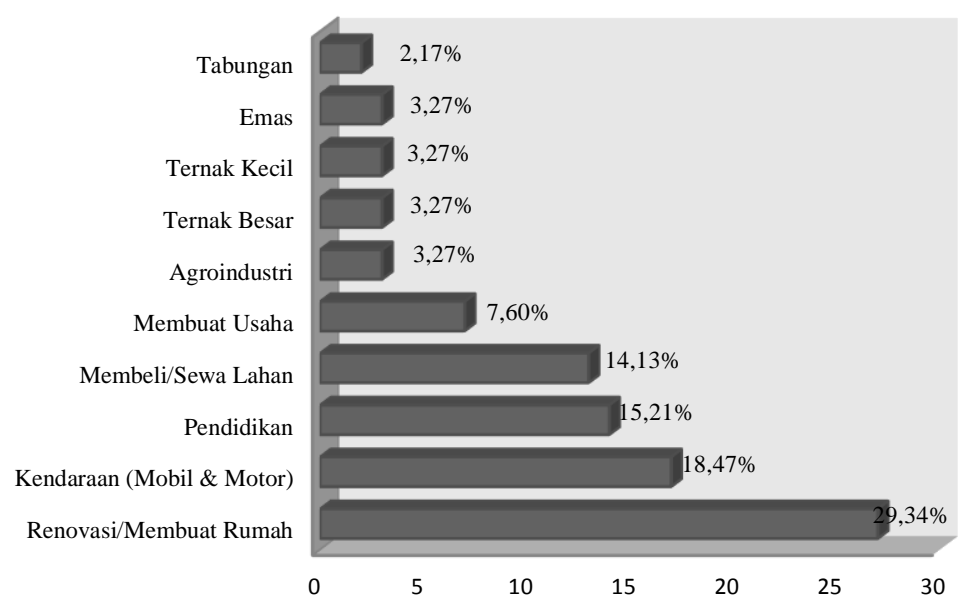

Figure 2. Types of Investment Allocation

The results show that the female workers who invest its money in the form of house construction are as many as 27 
informants with a percentage of $29,34 \%$. In the second sequence, the investment is in the form of purchasing vehicles (motorcycles \& cars) with a number of 17 informants $(18,48 \%)$ followed with education as many as 14 informants $(15,21 \%)$. The other 7 informants $(7,60 \%)$ said that their allocation of investment is in the form of business. There are also 3 informants $(3,27 \%)$ who invest its money in agroindustry, large livestock, small livestock, and gold. The last investment allocation is in the form of savings with a number of 2 informants $(2,17 \%)$. The types of investment allocation as mentioned above can be explained in this following section.

The results of the data above point out that most of the female workers spent its money to build or renovate houses with a total of 27 informants $(29,34)$. Building or renovating a house is a thing that requires a lot of money so that it is no wonder if the money earned is spent only to invest in the form of a house. In general, the houses built by female workers are good and big. When viewed from the aspect of investment, house construction has an increasing selling value from year to year. By that, investment in the field of house construction will always have an added value. Even though the house will not be sold, this will provide a sense of comfort for the owner.

The form of the house which was built by female workers from the utilization of remittance in Majangtengah village is physically visible. There are changes as before and after becoming female workers abroad. The condition of the family before they work abroad are still relatively ordinary and simple, however, after they work abroad, their house change into a relatively modern and minimalist house.

Remittances can affect the condition of the house and the development of Majangtengah village. Female workers assume that building a house is one of the hallmarks of their success in working overseas besides the other needs. The results indicate that an investment in the form of houses is the first choice in determining the utilization of remittances. After that, the rest of the money is used as a capital for business and to buy household needs. This is reinforced by a statement from one personnel in Majangtengah village which said that the female workers often invest their money mostly to build a house.
The second type of investment is in the form of a vehicle purchase, both two-wheeled and four-wheeled vehicles. The number of informants who allocated their remittances to purchase vehicles is as many as 17 people with a percentage of $18,47 \%$. They buy a vehicle to facilitate the family in business and in traveling matter. They also said to ease the children to go to school.

The investment in the form of education is one type of investment that is profitable in the future and able to provide economic and non-economic benefits. According to the theory of Human Capital, investment in this field has increased the human resources in economic benefits such as gaining additional income if one's education level is higher than the others. As for the non-economic benefits, high education level will give the better working condition, job satisfaction, and consumption efficiency.

The remittances used for children education can provide other benefits such as they can attend school and improve the education level in Majangtengah village. If many children fulfilled their education, it might help develop the mindset of the children in the future. The use of remittances in tuition fees is a long-term investment for the families of the female workers. In the future, it is expected that they can advance the level of higher education. The cost of education can be seen from the school uniforms, stationery, school books, the cost of education and contributions (biaya sumbangan pembinaan pendidikan or SPP), and allowance.

Based on the results of the survey, 14 people $(15,21 \%)$ of 30 informants chose to utilize the remittances into the cost of education. Besides to improve their family's economic condition, the female workers believe that it could help the husband or parents to meet the cost of education for their children or younger siblings. One of the informants stated that her reason to go to work abroad is to realize the dream of her son to enter college, besides to make a house.

The next allocation of investment is the purchase or lease of a land. In general, the land investment is used as moorland and rice fields. This became the third choice after house construction and education because of the majority of the people in Majangtengah village work as farmers and farm laborers. Therefore, after the female workers return from abroad, 
they have a self-managed farmland. On the other hand, land investment also has a high selling value which will increase from year to year so that many migrant workers like to invest their money for this matter because it provides added value.

The purchase of a land is basically seen from the characteristics of Majangtengah village which have a potential in the agricultural sector. They do not buy in the area only but also outside Majangtengah village. This type of investment is usually used to build houses and agricultural land. The results of these agricultural commodities can be sold and can be used to meet the needs of daily consumption. The yield of paddy fields also can be used for consumption and, if it comes on a large scale, it can be sold to meet other needs.

The land is usually managed by their husband or families by making it available for a rent or for a state-owned enterprise. This usually planted with high-value annual crops or seasonal crops. The types of annual crops are sengon trees while the seasonal crops are cassava, peanuts, papaya, chili, and corn. Those seasonal crops might be used for selfconsumption and to be sold. The largest area which is rented by a full-time female worker is 4-5 hectares. One of the 30 informants also offered to rent her farm to another person with a period of three years. The results of the rent money are used for family purposes.

The next utilization of remittances from the female IMWs is used as a capital to open a business. Business is one of the family economic activities used to meet the family needs maximally. The business established by each informant is different. There are some informants who started their business after they return to the hometown and there are several businesses that have been pioneered since they still working overseas. The informant who has a venture wants to expand the business to become even bigger.

7 people $(7,60 \%)$ of 30 informants have business after they work as female IMWs abroad. The business is in the form of stalls, farm shop, sound system engineer, garage, rice digger, and tailor. The 7 informants chose to use their remittance as capital to make business because, besides their own will, they want to maintain the necessities of life. They also want to continue the previous business rather than to go back to work abroad or unemployed. The following statement is obtained from one of the informants at the interview which is Mrs. Yuni, 45 years old:

"...I feel urged if I'm unemployed. I really want to work, want to seek business instead of doing nothing. You know, I also still young... I can't rely on my husband only, I have 3 kids and none have married..."

Established businesses are usually managed by husband or wife, sometimes it is managed simultaneously and also run by relatives or their own families. In addition to the family, some types of businesses require labor from outside the family. This can reduce the unemployment rate in Majangtengah village and can improve the economic status of the village. One of which is the garage business, farm shop, and sound system engineering. These types of business can facilitate Majangtengah village itself because if the villagers need something, they do not need to find the facility in other areas.

Agroindustry is one of the choices made by female workers in utilizing the remittances for productive activities. Agroindustry is a type of business that utilizes agricultural products in a broad sense to provide added value for agricultural products. The agroindustry business is in the form of home industry which made kripik talas, rempeyek, and birdcage. These businesses are performed by 3 informants. This can contribute to longterm incomes and can assist the meeting of their daily needs.

The other remittances are invested in the purchase of large livestock, small livestock, and eggs business. From 30 informants who have been interviewed, there are 6 people who choose to open livestock business. Large livestock is generally an alternative option for former retired female workers to utilize the money they earn. The major types of the livestock are cows and goats. Besides the migrant workers, there are some other people who also choose this business. On the other hand, the potential of Majangtengah village is very helpful for the availability of animal feed itself. It is known that the village has a potential in sugarcane cultivation. So, the leaves from the sugarcane harvest can be given as cow's and goat's feed. Most of the sugar can businessman leave the sugarcane leaves dried out and not properly managed so that the 
owners of large livestock can take the sugarcane leaves to feed their animals without paying.

From 30 informants, there are amounted 3 people who have small livestock. The types of livestock are chicken broiler and duck. They choose this business because they follow friends or husband. All three businesses are managed by husband and wife without outside workforce. The utilization of remittances in this business can provide benefits because chicken, duck, and egg have high potential. This is because the demand for chicken and duck eggs itself is very high and is one of the human needs. Chicken broiler also one type of investment that is promising because the demand for chicken meat is very high and is a type of protein consumed by many communities.

The last type of investment allocation is in the form of savings and the purchase of gold. The number of informants is as many as 2 people with a percentage of $2,17 \%$. An investment in the form of savings is part of financial planning that is used for financial needs in the future. The profit derived from this investment is the added value obtained from the savings in the bank with the amount of interest that has been determined. As for the type of investment in the form of gold, it is a utilization of remittances for a long-term planning. Gold has a price that tends to increase which can provide added value for female workers although the results might not be greater than the investment in the business.

\section{Conclusion}

It is concluded that in South Malang, the socio-economic transformation of the family occurs through the migration of female workers into IMWs. The transformation occurs in the structure and function of the family with the success of the female actor as a driver for the family and the village economy level. The success or failure of IMWs to build the family's economy level is largely determined by its home environment, workplace environment, work habits and ethics, as well as motivations that encourage them to work. The factors that drive IMWs battle in the destination country are the work skills, adaptability, and the ability of the family to utilize the remittances obtained.
Majangtengah village has the potential to be developed on the basis of agricultural business and other productive enterprises according to the skills of the IMWs and the families. There are many local resources, agricultural wastes, and high potential of the undeveloped business. However, the professionalism, work skills, and remittances utilization of the female IMWs as domestic workers need to be paid attention from the beginning so that the work of the female IMWs is optimally beneficial.

\section{Daftar Pustaka}

Barbone, Luca., Katarzyna Pietka-Kosinska, dan Irena Topinska. 2012. The Impact of Remittances on Poland's Economy. Case Network E-briefs. No. 12 pg. 1-4.

Connell, John dan Richard P.C Brown. 1995. Migration and Remittances in South Pacific: Toward New Perspective. Asian and Pacific Migration Journal. Vol. 4 (1)pg. 1-33.

Cuong, Nguyen Viet. 2009. The Impact Of International And Internal Remittances On Household Welfare: Evidence From Viet Nam. Asia-Pasific Development Journal. Vol. 16 (1) pg. 59-77.

Curson, Peter. 1981. Population Geography: A Journal of Association of Population Geographer of India, Volume 3.

Friedman, J. 1992. Empowerment : The Politics of Alternative Development. Blackwell Publishers. Cambridge. USA.

Irawaty, Tuty dan Wahyuni, Ekawati Sri. 2012. Migrasi Internasional Perempuan Desa danPemanfaatn Remitan di Desa Pusakajaya, Kecamatan Pusakajay, Kabupaten Subang,Provinsi Jawa Barat. Research Paper Sains Komunikasi dan Pengembangan Masyarakat FEMA IPB Vol. 1 (4) hal. $1-53$.

Primawati, Anggraeni. 2011. Remitan Sebagai Dampak Migrasi Pekerja Ke Malaysia. Sosiokonsepsia, Vol. 16 (2) hal. 209222.

Rapoport, H. dan Docquier, Frederic. 2005. The Economics of Migrans, Remittances. Discussion Paper No. 1531. 
Retno, Ratri Noor Hayu. 2014. Analisis Keputusan Investasi Oleh Tenaga Kerja Indonesia (Studi Kasus di Kecamatan Watulimo Kabupaten Trenggalek). Fakultas Ekonomi dan Bisnis, Universitas Brawijaya.

Sukesi, Keppi, 2005. Dampak Migrasi Internasional terhadap keluarga. Laporan Penelitian, tidak diterbitkan.

Wijaya, Hesti. R., Pandriono, Sugiyanto dan Heru Santoso. 1999. Liku-liku Perjalanan TKI-TKI Tak Berdokumen ke Malaysia. Gama Press. Yogyakarta.

Wijaya, Hesti R, Keppi Sukesi. 2012. Model Perekayasaan IPTEKS Sosial Bagi Wanita Pekerja Kontrakan Luar Negeri di Tempat Kerja: Kebijakan Perlindungan Tenaga Kerja Indonesia di Hongkong. Direktorat. Jenderal Pendidikan Tinggi, Kemendiknas.

Wiyarti, Sri dan Sutapa Mulya. 2007. Sosiologi. UNS Press. Surakarta. 